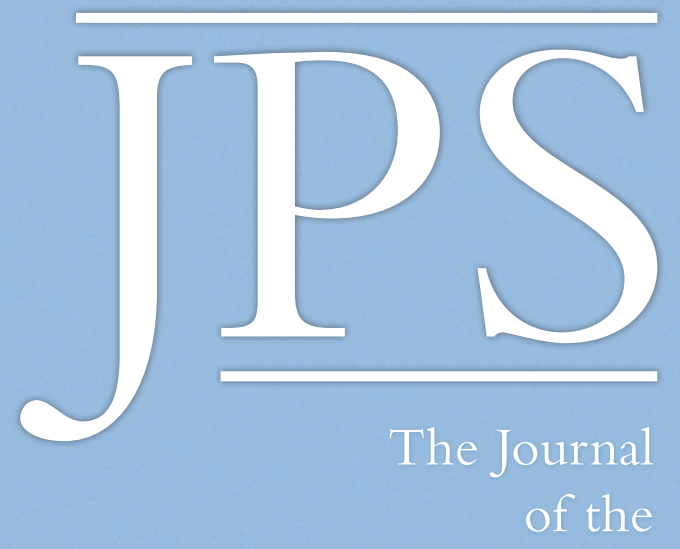

Polynesian Society

VOLUME 126 No.3 SEPTEMBER 2017

THE POLYNESIAN SOCIETY THE UNIVERSITY OF AUCKLAND NEW ZEALAND
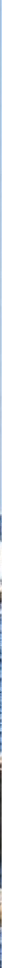


\title{
THE TREASURED THINGS OF TOKELAU
}

(Nayacakalou Medal Lecture)

\author{
JUDITH HUNTSMAN \\ University of Auckland
}

Tokelau's most treasured things are tifa 'pearl-shells' that are fashioned into $p \bar{a}$ 'lures for skipjack (Katsuwonus sp.) casting' and kahoa 'pearl-shell pendants'. People say that pearl-shells are "the gold of Tokelau", comparable, said one man, to the whale teeth of Fiji. More commonly, like other things that are highly valued, pearl-shells are referred to as tāua 'important/precious', thus mea tâua 'treasured things'. Visitors in 1841 recorded that the interior of the Fakaofo god-house was hung about with pearl-shells, and later visitors, as well as written and oral Tokelau accounts, expand upon this observation. Drawing upon ethnographic data, historical accounts and reports, Tokelau texts and a unique and enlightening kakai 'fictional narrative', I explore why tifa, $p \bar{a}$ and kahoa are Tokelau's most treasured things. The other valuables of Tokelau are kanava trees/taiulu timber (Cordia subcordata), kie pandanus (Pandanus freycinetia) and vai magalo 'fresh water', each resource emblematic of one or other of the atolls. Tala 'traditional narratives' explain why. These "singular" (versus "common") ${ }^{1}$ resources, their associations, their uses and how things produced from them are transferred set them apart as well. The most valuable things - pearl-shells and the $p \bar{a}$ and kahoa fashioned from them-are panTokelau treasures sourced from the sea; the three valued resources-kie pandanus, fresh water and kanava timber - are atoll-specific. Yet, in certain past and present contexts the treasured items fabricated from kie pandanus are paired with those fashioned from pearl-shells. These statements entail an engagement with Tokelau cosmological ideas of the past and their reflections in the present. However, a few matters need to be addressed before I turn to the treasures.

Tokelau is three classic atolls, lagoons surrounded by irregular rings of coral on which perch coral-rubble islets densely covered with vegetation under a canopy of coconut palms. The atolls, Atafu, Nukunonu and Fakaofo, are located far enough from each other that movement between them is constrained, and each has its own people, its own genealogy and history and its own characteristic ways of doing things. Yet, all Tokelau has a common language and culture, distinctively different from those of its Polynesian neighbours - Sāmoa, Tuvalu and the northern Cook Islands some 500 to 1,000 kilometres distant. The villages, one on each atoll, are densely peopled and very busy places - children playing, carrying and fetching fill the paths, as do their parents and grandparents engaged in their everyday tasks and going to or returning from numerous village meetings, gatherings and events. And 
all of this activity is carefully programmed and controlled by the elders. A Tokelau village, as they say, is a nuku pulea 'controlled/ordered village'. Numerous islets around the lagoon are divided into named plantations, and the reefs and ocean abound with sea life. Men harvest from the plantations and capture fish from the sea; women receive, distribute and process the produce and catches. Tokelau is not an unchanging place, but this essential way of life persists despite events in the past and changes in recent years that have challenged it.

Neither local histories nor accounts of visitors speak of any regular contact between Tokelau and its far-flung neighbours. Indeed, Horatio Hale (philologist and ethnologist of the U.S. Exploring Expedition) wrote: "They appeared, indeed, to know the names of Viti, Tongatabu, and Samoa, but not the direction in which they lay" (Hale 1846: 155). An archaeologist unearthed exotic/imported items in the atolls, e.g., pieces of basalt adzes chemically sourced to Sāmoa and potsherds sourced to Fiji (Best 1988), but by what route they got there can only be guessed. I think it can be assumed that the three atolls of Tokelau did not engage in any kind of regular transfer of items beyond Tokelau itself. Thus, my discussion here is microcosmic, concerned with what things and how things are and were transferred (or not) within and between the three atolls.

The ethnographic record provides abundant evidence that reciprocal or dyadic exchange transactions have not been a feature of Tokelau sociality either in daily life or on marked occasions. ${ }^{2}$ What is so characteristic of Tokelau is how much time and energy each day is devoted to dividing, distributing, contributing, sharing and transferring items in prescribed ways both within a village through inati 'share units', ${ }^{3}$ and within kaiga 'kin corporations' specifically, and also 'families' in several senses and 'relatives' in a general sense (see Huntsman 1971, 1981; Huntsman and Hooper 1976: 109-21). I would venture to give two reasons for this insistence on sharing and distribution. First, within Tokelau communities, hierarchy is suppressed by a clearly articulated and practised egalitarian ethic, albeit with notable precedence accorded the elderly. Second, Tokelau's villages are circumscribed, densely peopled and largely endogamous - their populations ranging around 500 in recent years. Third, kin relations form a dense network of responsibilities and expectations, owing to the thoroughly cognatic principles of corporate kin group affiliation, so that most villagers are included within multiple käiga. The village polity is referred to rhetorically as a kaiga, for example, and its elders as fathers and mothers. Just about everyone is kin in some close or distant way. ${ }^{4}$

The prime inalienable and "singular" things held by Tokelau kāiga, as corporate kin groups, are land, created by remote ancestors by clearing 
bush and planting coconut palms, and canoes, adzed from kanava timber. ${ }^{5}$ These things are the ola 'life' of the käiga, literally inalienable, created and maintained by forebears to sustain them and which present generations should maintain and regenerate for future generations. What then happens to them when a particular käiga breaks up (kua malepe te käiga)? The parcels of land and canoes (or canoe hull sections) are divided among its constituent branches, i.e., they divide among themselves those things that could never be alienated. ${ }^{6}$

Turning now to treasured Tokelau things, I consider in turn (i) observed marriage celebrations and a Tokelau-authored text on the subject, (ii) a Tokelau text explicating the proprieties of "gifting" particular treasures, (iii) a Tokelau kakai and a couple of "just-so" stories, and finally (iv) accounts of pre-Christian Tokelau by visitors and today by Tokelau raconteurs. In (i) and (ii) brothers and sisters figure centrally in the way Tokelau "singular" objects are handled, how they are transferred in marked ways within particular relationships and (iv) how, in the past, they were transferred in other ways too-demanded as tribute or "gifted" as offerings. The story (iii) provides the key to it all when viewed as a cosmological or mythopoetic narrative, rather than just an entertaining kakai.

\section{CELEBRATIONS OF MARRIAGE IN NUKUNONU ${ }^{7}$}

All the ways and meanings of transferring things - both "common" and "singular"- occurred in the course of Nukunonu marriage celebrations in the late 1960s. I consider first one of these "common" things, namely food.

The symbolism of combining and sharing food is particularly salient and explicit on the occasions of marriage. Several käiga, specifically corporate käiga of which the girl and boy to be wed are members, together provide and together apportion the lavish wedding feast to celebrate a marriage that promises to produce a new person who will be kin to them all, and they collectively feed the village by providing an abundance of food to be distributed through inati.

As many as eight käiga may host a wedding celebration, representing the eight grandparents of the boy and girl who are marrying. Each separately amasses an abundance of foodstuffs: harvested from their plantations, caught from their canoes, and imported commodities, such as flour and sugar, bought with money received from producing copra. On the day of the wedding, colourfully dressed and bedecked with garlands, gaily singing and carrying the food they have cooked, these käiga converge on the place where the wedding feast is to be held. This convergence is neither en masse nor direct; rather their routes retrace former käiga unions that brought into being and nourished the life of the boy and girl whose union is about to be celebrated. Finally they 
all arrive at the home of the boy's father's sister, each käiga displaying its collective feast contributions with song and splendour. The food is sorted by type (pork, fish, breadfruit, puta 'doughnuts', etc.), and then portions of each are placed upon platters and into baskets, including a single platter for the ulugāliki fou 'new couple' and smaller platters for the couple's grandparents and other elders, who collectively represent the village. Thereafter baskets of food will be distributed among the hosts, and finally to every inati in the village. All this preparation, display, combining, sorting and presenting is replete with Tokelau meanings of kai fakatahi 'eating together', as a couple, as a käiga, as a village, and mirrors on a grand scale the continual flow of "common" consumables in everyday life.

Treasured "singular" things are essential for a marriage and are handled quite differently. While the foodstuffs for the wedding feast are being carried about, the couple are being churched, the girl dressed in a white wedding gown and veil, the boy in a sombre suit, thereby becoming a fafine fou 'new woman', a tagata fou 'new man' and together an ulugāliki fou 'new

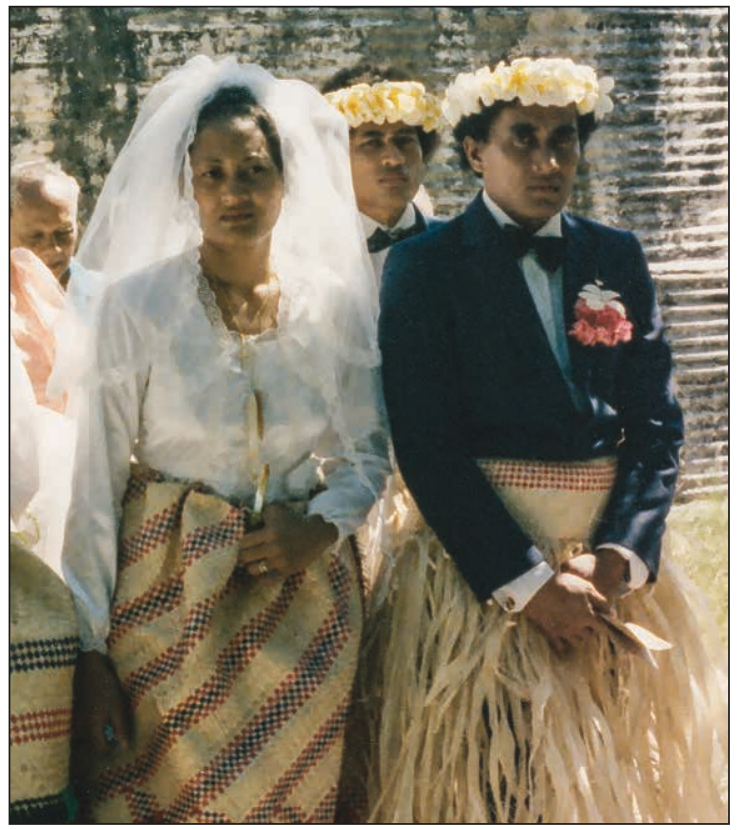

Figure 1. New couple prepared for tūala 'viewing' (lit. 'path-standing'). Author's photo, 1986. 


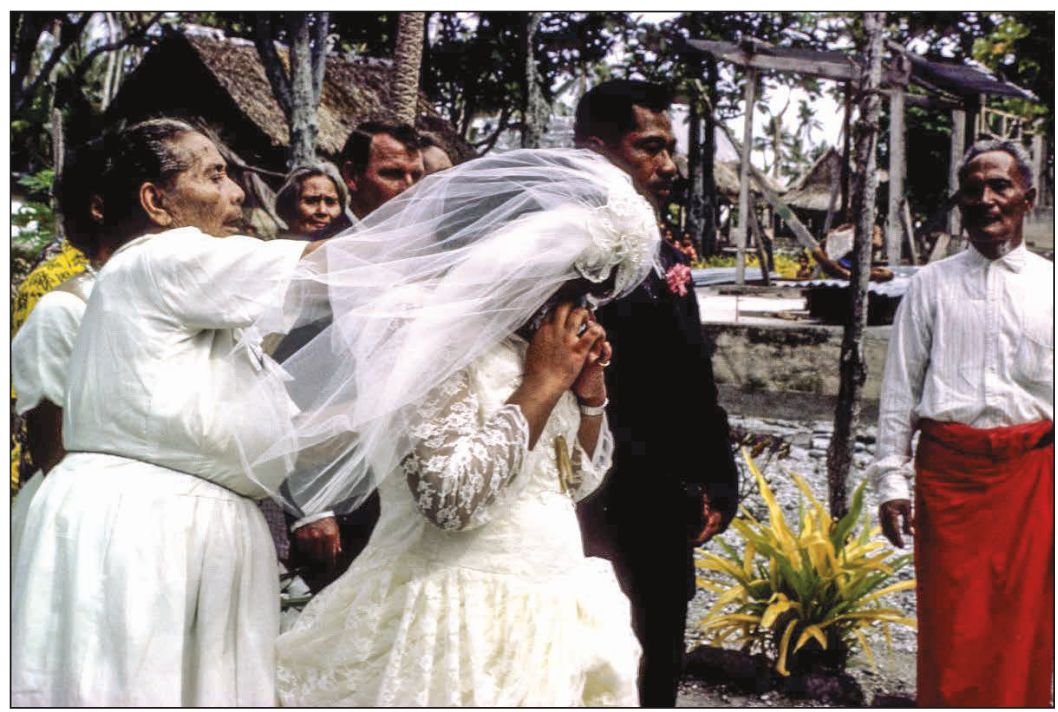

Figure 2. The new woman with a kahoa placed around her neck by her mother's father (at right). Author's photo, 1968.

couple' (Fig. 1). The ceremony is lightly attended; the real wedding begins with the tüala 'viewing' (lit. path-standing) of the new couple. They appear conspicuously in the village path, donned in their Tokelau garments and decorations of marriage. Over the new man's sombre suit is tied a reformed version of a loincloth (malo) woven of kie pandanus by his father's sister. Upon the neck of the fafine fou is a kahoa, placed there by her mother's brother (or father) (Fig. 2). These Tokelau treasures, the kie pandanus garment and pearl-shell pendant, are "gifts" to the marriage. Not only are they "gifts", they are the most significant ones, both for what they are and for who gives them. From the woman's side is "gifted" the pre-eminent men's treasure, for the new woman's pendant is not just an ornament, it is an unbound $p \bar{a}$. The new woman takes the pendant into her marriage to be properly bound again and put back to use as a lure. From the man's side are "gifted" pre-eminent women's treasures, not only his malo but also a kiekie 'fine pandanus mat', referred to as the moega moe 'sleeping mat' of the new couple. The malo, bound around the groom by his father's sister, and the sleeping mat, presented by his father's sister, go into his marriage blessing the fruitfulness of the union.

Bedecked in Tokelau treasures, the new couple begin their slow circuit of the village accompanied by their attendants and followed by village elders 
and matrons singing a particular genre of pehe anamua 'songs of old' that celebrate a new couple. The procession ends at the house where the food is already assembled, and there the ulugāliki fou is feasted and entertained by their combined kaiga. All have come together: the new couple being celebrated, their several kaiga and the food they have provided, and the elders and matrons representing the village. The new couple are repeatedly urged to fai koulua kāiga fou 'make your new family', with wishes for manuia 'good fortune'. The woman's kahoa and the man's malo and moega moe (Fig. 3) are visible expressions of these hopes and wishes that in due course a käiga fou 'new family' will come into being with the birth of a child who will be of the several käiga of them both. ${ }^{8}$

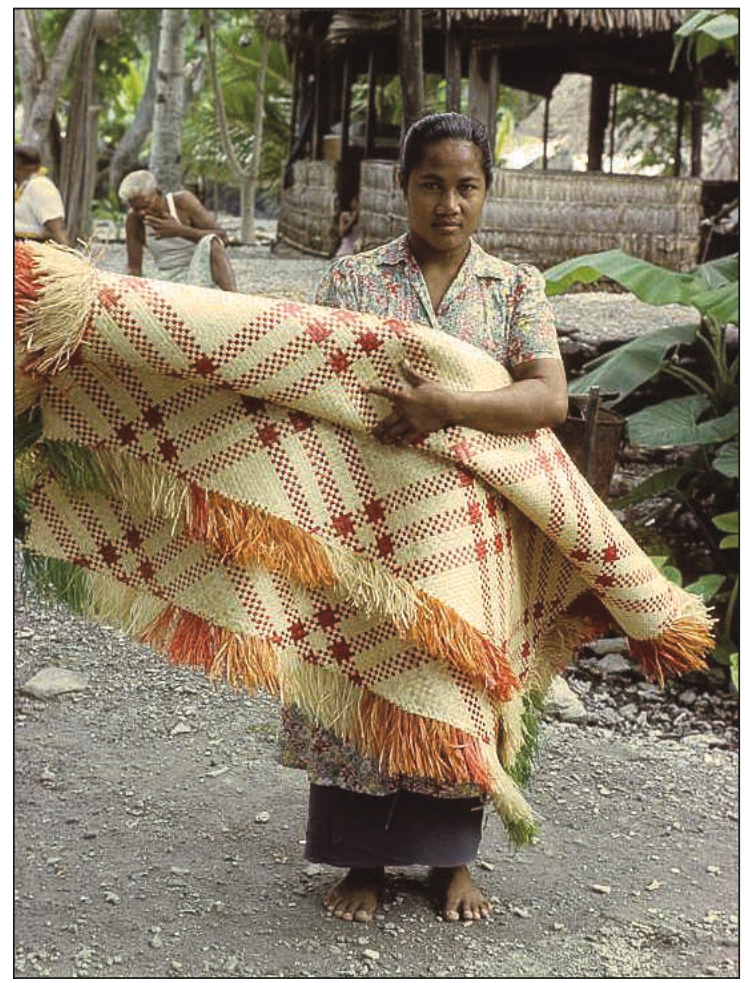

Figure 3. Moega moe 'sleeping mat' for new couple plaited by boy's father's sister. Author's photo, 1967. 


\section{THE WAY OF MAKING MARRIAGES}

The following is translated and abridged from the Fakaofo text composed by the late Peato Tutu Perez. ${ }^{9}$

The man is attired in his own home, and likewise, the female is attired in her home. When finished, the man and his whole family proceed to the woman's family and then tüala $i$ te auala ['present themselves in the village path']. They sing Tokelau songs that were customarily sung in the old days as well as the present.

\section{Tūalaga [lit. 'Path-standing']}

There are two particular pala [sites in lagoons where a soft whitish sediment lies on the bottom] in Fakaofo: Pala o te Loto ['Deep Place'] and Pala o te Tuāa $\bar{a} a i$ ['Back of Reef Place']. If a pearl-shell is found there, that pearl-shell will kaina (excite) the skipjack. These two pala are well known in Fakaofo, are cherished in Fakaofo, for a tifa found there will attract skipjack.

When the married couple present themselves on the village path, the older women exclaim that the bride is a pearl-shell. These are the words that the old women call out, while the older people of the village sing the songs of the tüalaga.

$$
\begin{aligned}
& \text { O! ..., he tifa! ..., he tifa fou! ..., mai te Loto! } \\
& \text { O! ..., he tifa! .., he tifa fou! .., mai te Tuāālai! } \\
& \text { O! ..., a pearl-shell! ..., a new pearl-shell! ..., from the Deep Place. } \\
& \text { O! ..., a pearl-shell! ..., a new pearl-shell! ..., from the Reef's Back. }
\end{aligned}
$$

\section{Fakakahoa ['Transferring $p \bar{a}$ as kahoa']}

This is not done lightly, especially when the daughter of a tautai 'master fisherman' is concerned.... It is the tautai who knows the $p \bar{a}$ most suitable for kahoa and those that are not suitable. This is how he knows. When skipjack are caught, their skins may be either shiny or rough. When they land in the canoe, they are not quick to thrash about, but lie still. They thrash about not long thereafter, and then you see their skin is gleaming on the backside, and the stripes on the underside just begin to appear [Fig. 4]. These stripes on the underside become more vivid when the skipjack is dead. When a skipjack is like that, it has been excited. It has been excited by the lure. These then are the $p \bar{a}$ suitable to give as kahoa. The tautai gives such $p \bar{a}$ to the head of the family as kahoa for the daughters of the family when they marry.

Now after the kahoa is put around the bride's neck, it is later removed by the senior tautai of the boy's kaiga.... In Tokelau customary practice too, the daughter of a tautai may have a p $\bar{a}$ placed around her neck as a kahoa and 
be sent off to go and stroll on the path. A person should not remove it unless he is a tautai, and he must not do so too often. It is unseemly these days the way kahoa are so often displayed [my emphasis].

Dressing of the Boy and Girl on the Day of Their Marriage

The garments are from their fathers' sisters. This means that for the boy it is the sister of his father, called his mätua tauaitu [lit. 'spirit-anchoring mother'].

For the girl it is likewise the sister of her father, her mātua tauaitu.

\section{Some Interpretation}

The author of this text (Fig. 5), as befits a renowned fisherman, emphasises the "singularity" of tifa/pearl-shell $>p \bar{a} /$ skipjack lure $>k a h o a /$ pendant, and the proprieties surrounding their transformation and transfer. Pearl-shell is sought (and rarely found) in particular places in the lagoon; the skipjack lures that are fashioned from it are used in the pre-eminent (and still ritualised) kind of fishing - known as ālo atu 'skipjack casting' (Hooper 1985, 2010; Hooper and Huntsman 1991) (Figs 6-8). Only when a lure has been proven effective, that is, kaina 'exciting' to skipjack, should it be transferred to another, and then not directly but via a woman. ${ }^{10}$

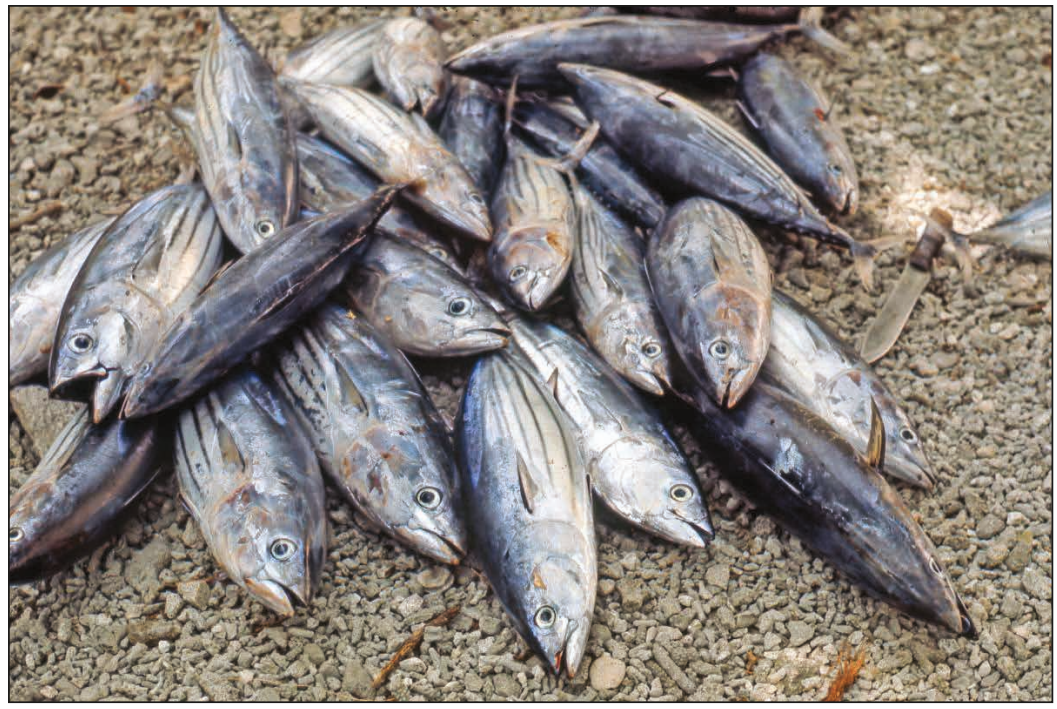

Figure 4. A few atu 'skipjack' showing stripes, indicating they have been excited (kaina). Photo by Marti Friedlander, 1971. 


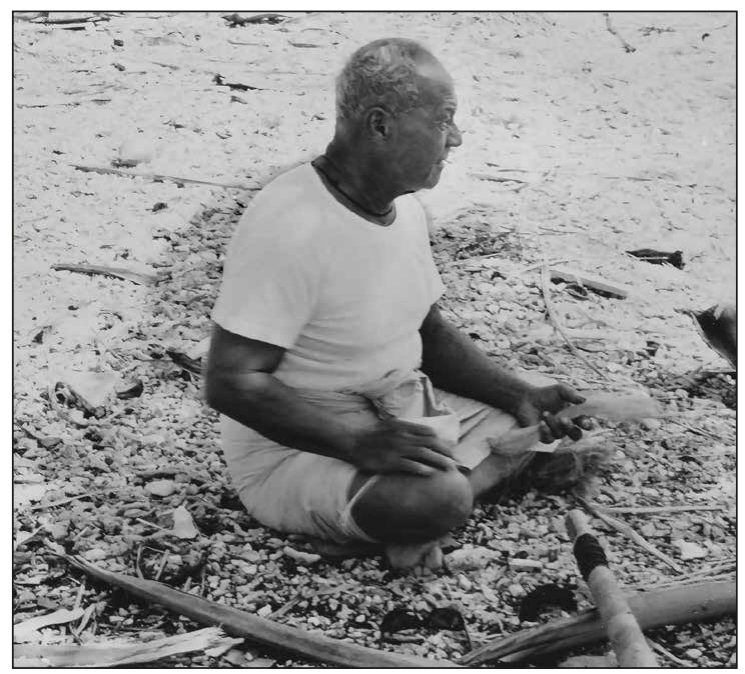

Figure 5. Peato Tutu Perez, 1968.

\section{Atu/skipjack or bonito lure}

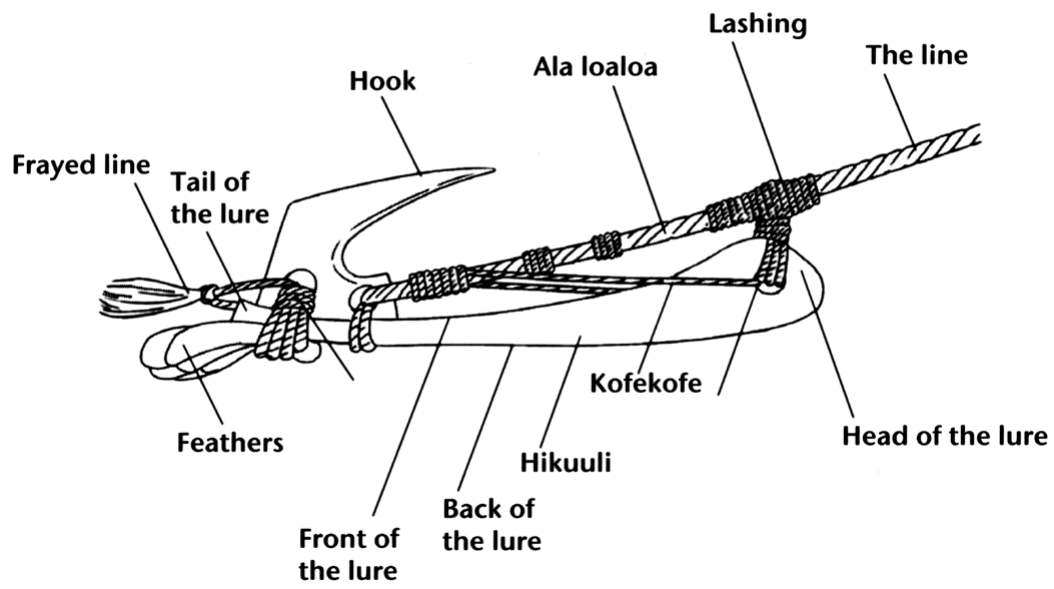

Figure 6. A pā properly bound. From Elders from Atafu Atoll, 2012: 73. 


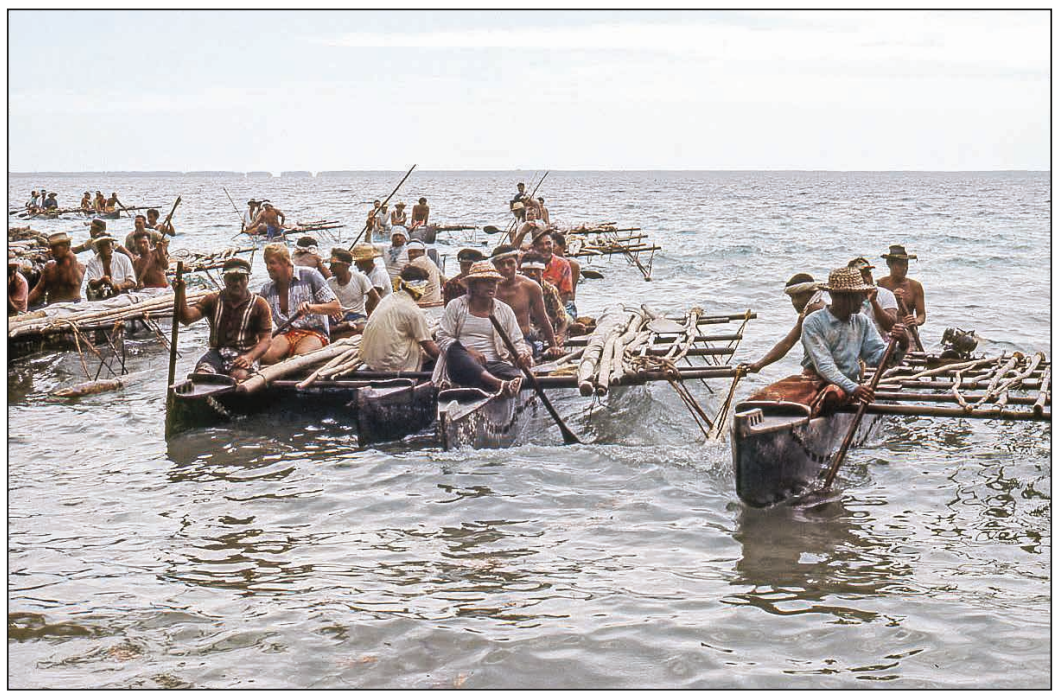

Figure 7. A flotilla of canoes returning from successful ālo atu 'skipjack casting'. Photo by Marti Friedlander, 1971.

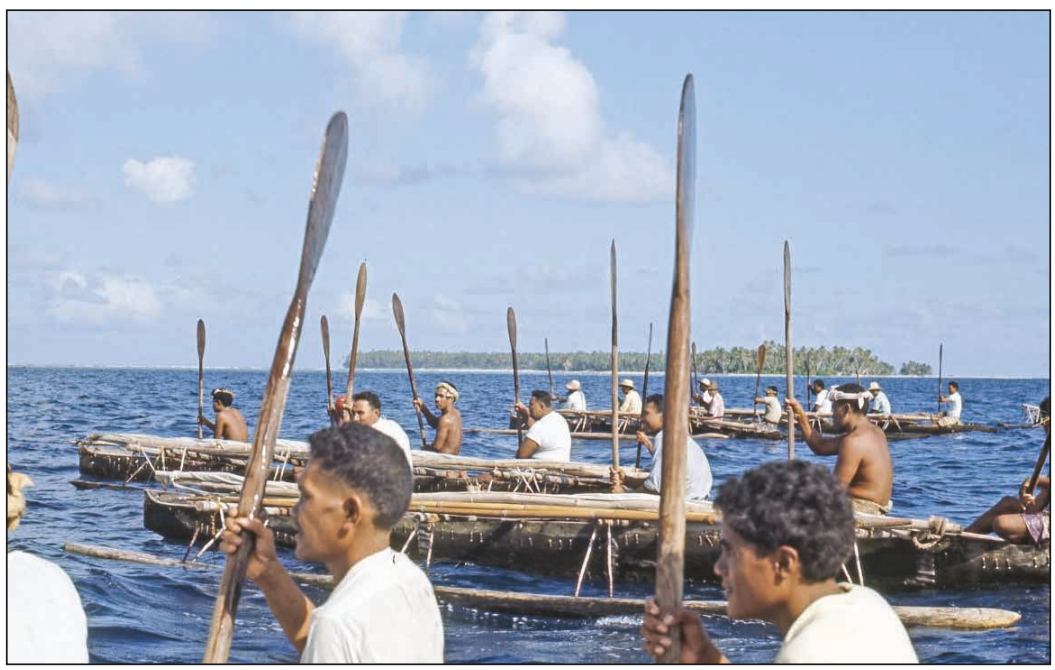

Figure 8. Flotilla of canoes returned from ālo atu with raised paddles indicating a large catch. Photo by Marti Friedlander, 1971. 
Tokelau men will spend hours gazing at and commenting upon the subtle hues, varieties and shapes of pearl-shells and lures. Cutting lure blanks from a shell and fashioning, refining and binding them to make a lure is a cultivated skill - not something undertaken lightly (Fig. 9). Although nowhere in the text is the etiquette of transferring these "singular" objects via women explicitly stated, it is what is in fact done. When men relate how they acquired their lures, they have most usually passed through women. Take this example: a man gave a centre section of pearl-shell to his sister's daughter, whose husband appealed to his elderly and knowledgeable father to shape it for a lure. The husband then successfully fished with it and subsequently placed it as a pendant around the neck of his own sister's daughter at her marriage.

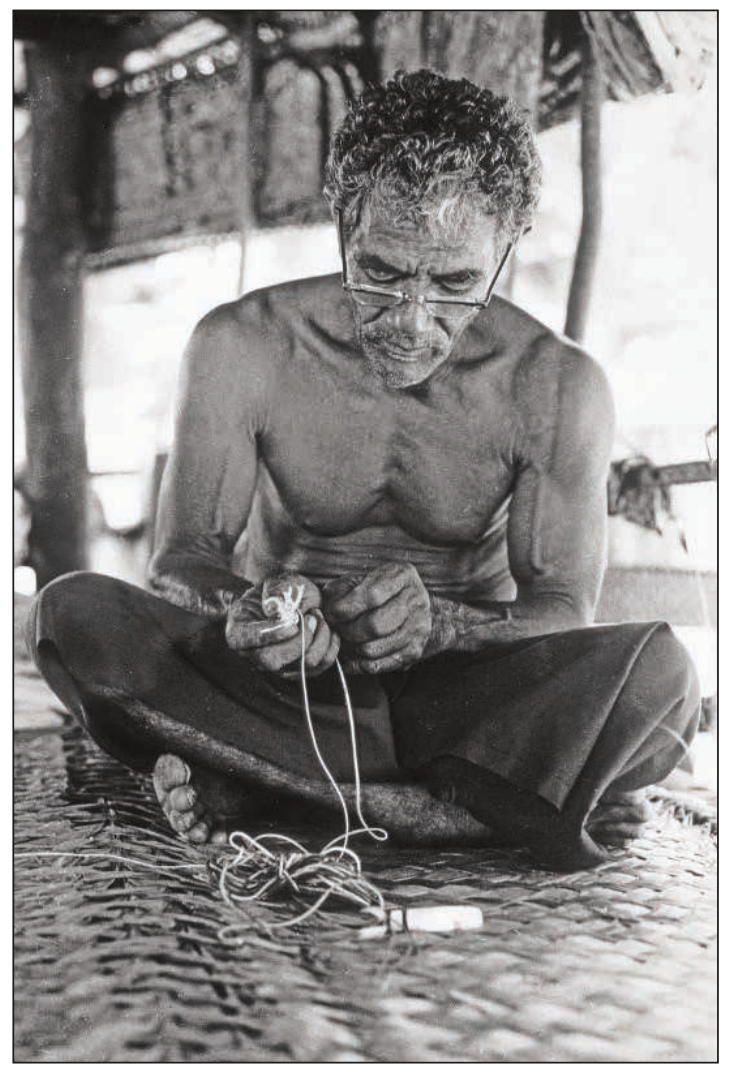

Figure 9. Fakaofo tautai checking line for $p \bar{a}$ in preparation for àlo atu. Photo by Marti Friedlander, 1971. 


\section{THE TALE OF THE PEARL-SHELL}

A Tokelau narrative from the English version of the Matagi Tokelau (1991: 212-19) text, considerably abbreviated here, tells the story of the original mother-of-pearl-shell/lure/pendant (see also Burrows 1923: 168-70).

The son of the Sun, following the instructions of an old woman whose sight he restored, journeys to the sky to obtain a tifa from his father for his pregnant bride, Hina, the daughter of Tui Fiti. After he has manages to grasp the packet containing the correct tifa, the Sun orders him not to unwrap the packet until he has returned to his mother, but alas, he disobeys. The brilliance of the exposed tifa, reflecting the rays of the rising Sun, dazzles the eyes of the Sun, who calls upon sharks to devour his disobedient son. The tifa slowly flutters to the bottom of the sea, and its flickering attracts skipjack. They nibble at it, shaping it into a kahoa, which becomes caught in the eye of a fish-trap belonging to Tui Fiti. When Tui Fiti's fisherman, Lakulu, raises the fish-trap, it is filled with skipjack attracted to the entangled kahoa. The kahoa, shaped by nibbling skipjack, is retrieved from the fish-trap by Lakulu and handed to Tui Fiti, who recognises it as the kahoa that the long-gone son of the Sun sought for his bride-Tui Fiti's daughter. He binds the kahoa as a $p \bar{a}$ and tells Lakulu to try casting for skipjack with it. Lakulu, now married to Hina, casts for skipjack with prodigious success. He becomes covetous of the $p \bar{a}$ and schemes to appropriate it for himself. He cuts the $p \bar{a}$ from the line and secretes it, telling Tui Fiti that the $p \bar{a}$ has been lost—he mala $t \bar{u}$ 'a great tragedy'. Shortly thereafter he proposes to voyage afar. Tui Fiti, suspecting that he has appropriated the $p \bar{a}$, warns that disaster will befall him if he has lied. The voyagers-Lakulu, his three sisters' sons and pregnant Hina - are beset by a storm. Lakulu and then his three sisters' sons drown in turn, each passing the appropriated kahoa/p $\bar{a}$ to the next before sinking into the sea, and the last passes it to Hina. Hina reaches land and delivers her boy child, the grandson of the Sun. When the boy is grown, he asks what the kahoa is for, and Hina replies: "Alas, that kahoa is mine, brought by your father. It is for ālo atu." After several attempts, her son finally succeeds in binding the kahoa correctly as a $p \bar{a}$ and to him skipjack swarm.

\section{Some Interpretation}

This is the only Tokelau tale I know of that has as its central character an object, and in a sense it relates the cultural biography of that object (Kopytoff 1986). The tale is, in fact, more mythic than fictional, because it accounts for the origin and properties of this treasure by embedding it in a distinctively Tokelau cosmic and social order (see Godelier 1999: 123, 134 and elsewhere on "the imaginary"). As the tifa is transferred and transformed from its source (the Sun) to its proper recipients (Hina and her son), it brings malaia 'disaster' and manuia 'good fortune'. It is repeatedly transformed and transmitted actually or symbolically through the agency of women. 
- A blind old woman directs the son of the Sun, who gave her sight, to reach his father and the pearl-shell he seeks in the sky.

- The Sun forbids his son to open the packet until he has reached his mother (who is entitled to it by virtue of their union).

- Fish attracted to the tifa shape it into a kahoa. ${ }^{11}$

- Tui Fiti recognises that the recovered kahoa was intended for his daughter and binds it as a $p \bar{a}$.

- The $p \bar{a}$ attracts many fish and the fisherman becomes covetous of it.

- He pretends it is lost and then takes it away.

- Tui Fiti's curse falls upon him and his sister's sons.

- The unbound pa , now a kahoa, comes into Hina's hands.

- And finally, Hina eventually passes it to her son who binds it again as a $p \bar{a}$ - to which skipjack swarm.

Men misuse this treasured object, disobeying their elders:

- The Sun's son, ignoring his father's instructions, unwraps the tifa and is devoured by sharks.

- The surrogate husband attempts to appropriate the $p \bar{a}$ that rightly belongs to Hina and her unborn son, and is drowned together with his sisters' sons.

Reiterated in episode after episode, pearl-shells must be transferred between men through women. The prescription still applies, but the cosmic order that informs it has been ostensibly abandoned. The belief that tifa was a "gift" of the Sun (or indeed of Tui Tokelau - see below) has become a fiction, still imagined in an entertaining tale that people delight in telling and hearing.

\section{OTHER SINGULAR THINGS}

The first among other marked Tokelau emblematic resources is pandanusnot just any type, but the species known as kie (P. freycinetia) from which fine, white, soft fibres are produced and plaited into delicate mats and garments (Fig. 10). Kie pandanus only flourishes in Nukunonu. Why it only flourishes in Nukunonu is explained in a well-known "just-so story" (see Matagi Tokelau 1991: 16-17; also Huntsman and Hooper 1996: 138). Briefly, very long ago the Fakaofo spirit (aitu) stole Nukunonu's vai magalo, and in retaliation, the Nukunonu spirit stole Fakaofo's kie pandanus. So it is that today Fakaofo has relatively abundant supplies of fresh water and Nukunonu has a plantation of kie pandanus, and it is indeed true that kie pandanus has yet to be cultivated successfully in Fakaofo and there is only a little, inaccessible well of fresh water in Nukunonu.

Another story with the same scenario accounts for the abundance of the canoe-building kanava timber in Atafu, where indeed there are more and 
larger trees of greater girth (Fig. 11). This story may well be derivative of the Nukunonu one - kanava trees simply replacing kie pandanus in the plot—and the story is only told in Atafu. This does not make it any less significant, however. Again, the Fakaofo spirit steals water, but then fresh water is present in Atafu, although not right within the village, and little fuss is made about it.

These stories would appear to place three "singular" resources more or less exclusively in the three atolls: fresh water in Fakaofo (Fig. 12), kie pandanus in Nukunonu, kanava trees in Atafu. Now fresh water is a rather different sort of valuable than pandanus and timber: it is not fabricated into anything

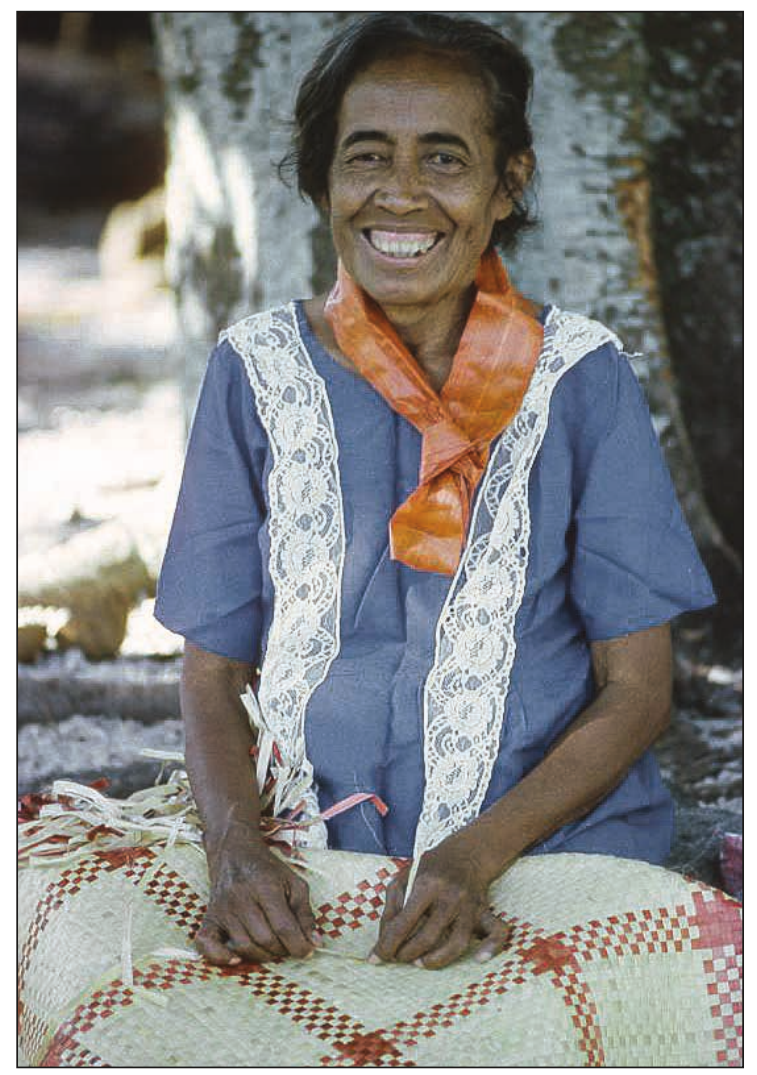

Figure 10. Nukunonu plaiting expert with a fine mat (kiekie) in her lap and a length of dyed kie pandanus around her neck. Author's photo, 1968. 


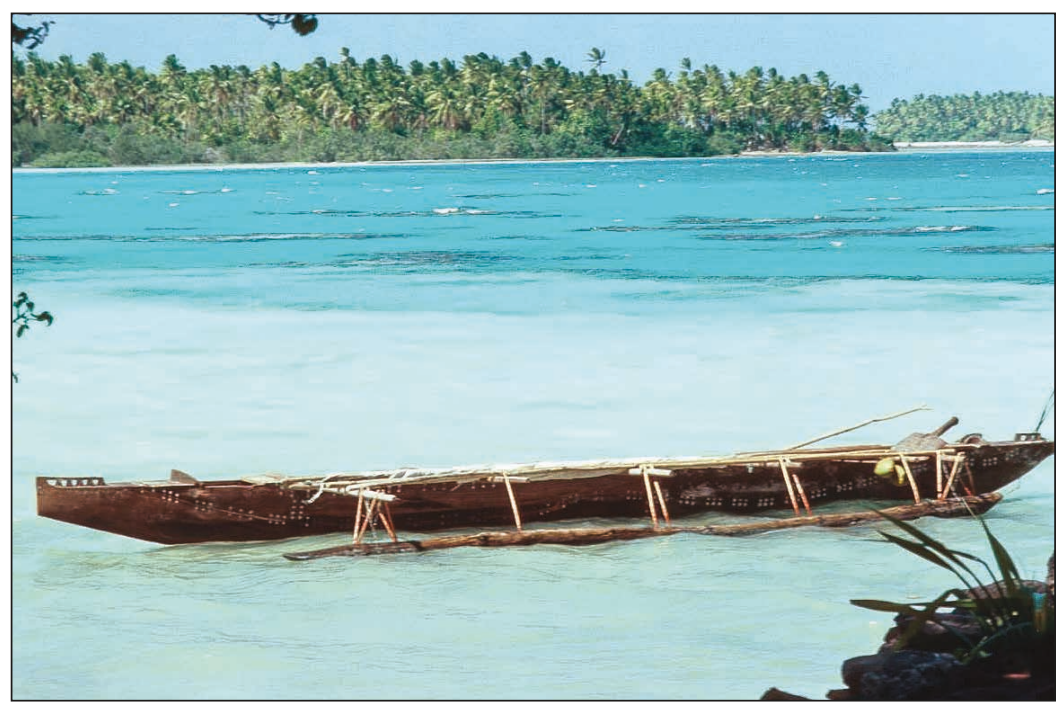

Figure 11. New outrigger canoe with kanava timber hull at anchor in Atafu lagoon. Author's photo, 1976.

and is more diffuse. Yet, pits dug into Fakaofo's freshwater lens support the cultivation of pulaka 'swamp taro' and a deep freshwater well still stands in the centre of Fakaofo village containing Fakaofo's "singular" valuable. The well was already there in 1841 .

At a little distance from the malae ['open space in front of the god-house where wrapped stones stood'] was a well about fourteen feet deep, neatly walled up, and surrounded by a high fence. There were not more than thirty inches of water in it, and from the care which was evidently taken of the place, it is probable that the pure element is an article of much rarity and value among them (Hale 1846: 158).

Near the centre of the Village is a well surrounded by a circular wicker fence about 60 feet in circumference - with a gate way entrance - and from which I presume all the inhabitants are supplied with water-This well is about 15 feet deep — of circular construction and excavated through the coral—or rather into it—and walled up about six feet from the bottom - with stones of five or six inches in diameter-I have an idea that it affords more water than is necessary for the use of the inhabitants. It had about three feet water in it - at the time of our visit. (Hudson, MS) 


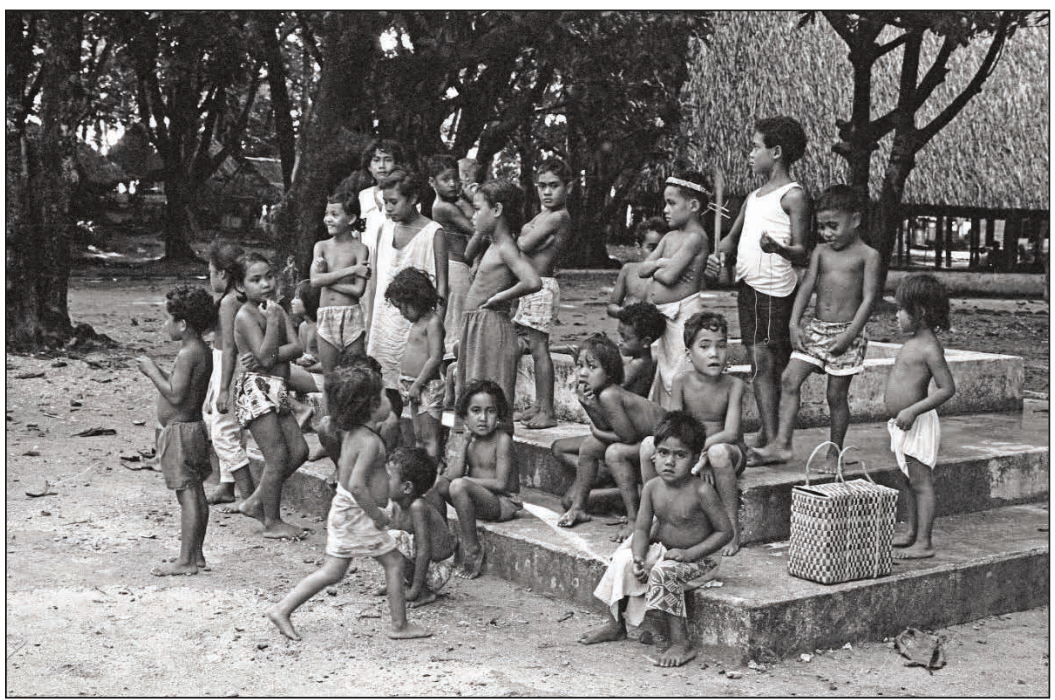

Figure 12. Fakaofo's fresh-water well. Photo by Marti Friedlander, 1971.

\section{TREASURES AND VALUABLES IN HISTORY}

From ancient times, though well after the mutual thefts (above) occurred, and into the mid-19th century, Fakaofo was the pre-eminent atoll of Tokelau. This had come about by Fakaofo's conquest of Nukunonu, and the abandonment of Atafu by its autochthonous people when faced with a Fakaofo invasion, and its later resettlement as an outpost of Fakaofo. Thus Fakaofo became overlord of all Tokelau and "the great god" Tui Tokelau became an apparent presence. ${ }^{12}$ Tui Tokelau was given concrete form in a huge coral-stone pillar concealed in matting that stood outside the god-house in Fakaofo (Fig. 13). The god's embodiment and house were the focus of the worship of Tui Tokelau, and the aliki 'paramount chief' of Fakaofo ${ }^{13}$ was the spokesman to and for the god, who was the source of all prosperity and blessings.

The worship of Tui Tokelau demanded significant offerings from Nukunonu. The most marked were the kiekie secured with a length of loincloth that enveloped the coral-stone pillar. Two 1841 firsthand descriptions are at odds regarding its dimensions, but not its appearance.

Whatever may have been inside was so thickly covered that it appeared like a pillar of matting ten feet high and as many in circumference. (Hale 1846: 158) 
The Gods or Idols were placed outside the Bure [god-house] - the greater one (at least in height) had an elevation of 14 feet and about 18 inches diameter - this was completely enveloped in mats with a narrow maro [malo] mat passed over it after the manner of a shawl-where we should look for a neck and shoulders (although this large Idol had neither head, legs, arms or more definable shape - than to say it was like a long bale of cotton stood on end) and tied with a flat knot in front - with the ends hanging pendant about four feet before the Idol. (Hudson, MS)

Following the abandonment of Atafu, parties from Fakaofo periodically voyaged there to fell and shape the atoll's kanava timber for canoes. When Atafu was resettled (c.1800), Fakaofo proclaimed to its pioneering residents this ominous warning: "You are absolutely forbidden to fell the bush of Togaleleva" (i.e., kanava trees dedicated to Tui Tokelau). The descriptions of the god-house in 1841 suggest the uses to which such dedicated timber was put.

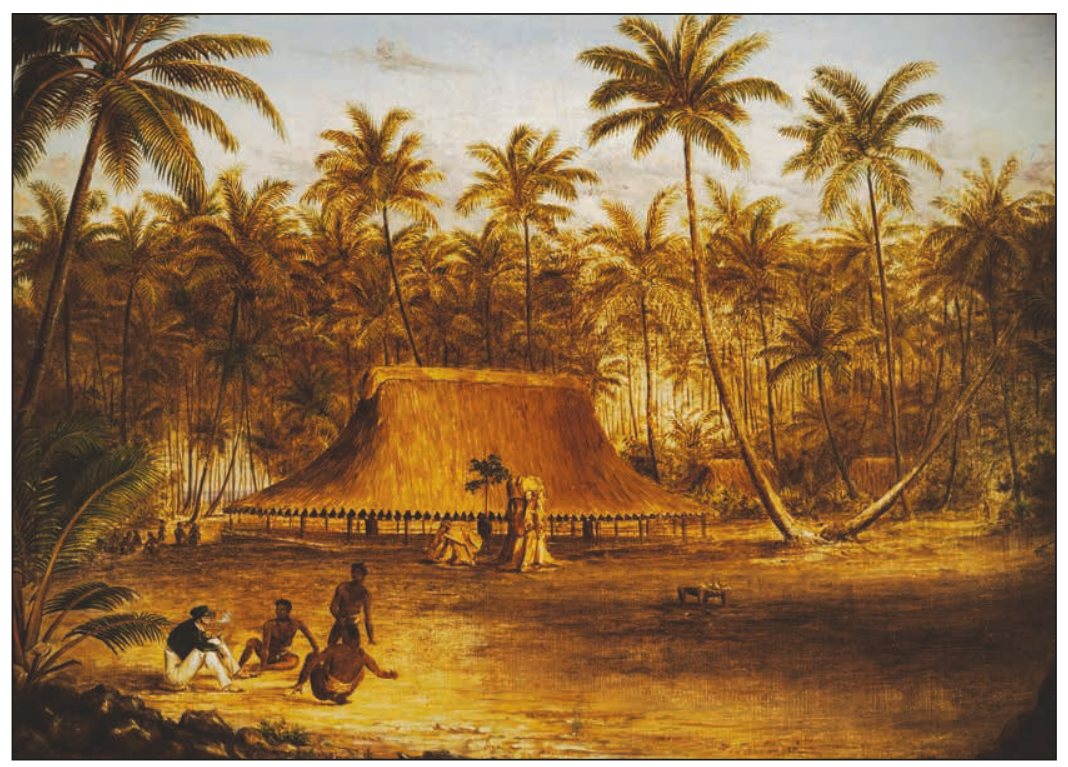

Figure 13. Tui Tokelau's mat-wrapped stone and god-house. Photo of painting by Agate, artist on the U.S. Exploring Expedition, from sketch made in Fakaofo, 1841. 


\begin{abstract}
Near the centre of the town was a large building, which they called the malae, and declared to be the house of their god, Tui Tokelau.... The house was oblong, about forty feet by thirty, and at the ridgepole about twenty feet in height.... The circumference was supported by many short stanchions, small and roughly hewn, placed a few feet apart; but the ridgepole rested upon three enormous posts, of which the largest was about three feet in diameter... In the centre of the house, about the largest post, were piled confusedly together a dozen massive benches, or large stools, two feet high, as many broad, and about three feet long; they were of clumsy make, very thick and heavy, each one being apparently carved from a single block. The natives called them "seats of the god," and we supposed that they might be for the elders of the village, when they meet in council, or for religious celebration. (Hale 1846: 157)
\end{abstract}

Two decades after Hale's visit, a missionary reported that a party of 200 Fakaofo people "had come down to this island to build canoes, as the wood suitable abounded here" (Ella MS 1861) - presumably in "the bush of Togaleleva", and, moreover, in this task they were assisted by the men of Atafu. Clearly, in this instance, Fakaofo was extracting both resources and labour from Atafu. Similarly, Nukunonu accounts assert that malo and mats plaited by Nukunonu women were used as coverings of Fakaofo persons, as well as shrouds of the god. How were these transfers perceived - as "gifts" and offerings or as appropriation and tribute or, indeed, differently by the different parties concerned?

This question is particularly pertinent in the case of pearl-shells, which if recovered in Nukunonu and Atafu were transferred to Fakaofo. As "gifts" or offerings they adorned the god-house: "Around the inside of the eaves, a row of mother-of-pearl-shells was suspended..." (Hale 1846: 157). According to some local accounts, only the flat side of each retrieved shell was dedicated to Tui Tokelau - the other side with its bulbous hinge was fashioned into lures for skipjack fishing (Perez 1992), but it is not stated whether Fakaofo retained both sides and thus held a total monopoly on pearl-shell. That is, were these pearl-shells recovered in Nukunonu and Atafu only directed to the worship of Tui Tokelau, or were they also appropriated for the benefit of Fakaofo - as were foodstuffs, other goods and Nukunonu women (see below)?

Undeniably, the transfer of treasures from Nukunonu and Atafu was based on Fakaofo's political overlordship underpinned by godly sanction. The specific inalienable resources relocated to Nukunonu and Atafu (kie pandanus and kanava respectively) by their "spirits" in retaliation for the Fakaofo spirit-theft of fresh water were the resources from which they fabricated the "singular" treasured objects that Fakaofo exacted from them (fine mats/malo and timber/canoes respectively). In essence, though Fakaofo could not regain those inalienable resources that only a spirit could relocate, Fakaofo did, in the name of Tui Tokelau, appropriate the "singular" objects fashioned from them. 
Yet, does the word "appropriate" reflect the thinking of the pre-Christian Tokelau ancestors? True, Atafu and Nukunonu people latterly viewed their tribute to Fakaofo and offerings to Tui Tokelau as subservience to a false god and oppressive rulers. They readily embraced Christianity in large part for these reasons, immediately ceasing to send either "gifts" or tribute (Huntsman 1994). Certainly a liberal Western interpretation would term the transfers appropriation, but did Tokelauans in the early 19th century think about it this way?

The huge stone pillar that "anchored" Tui Tokelau in Fakaofo was the "sacred" object (see Godelier 1999): inalienable, immobile and, indeed, hidden from the view of all but the aliki and his attendants who annually removed and replaced the fine mats that shrouded it. Tokelauans everywhere believed that Tui Tokelau was the source of prosperity, fertility and abundance, and their recorded prayers to him attest to this belief (Huntsman and Hooper 1996: 150-51; Matagi Tokelau 1991: 45, 48-49). Tui Tokelau, remote in the sky, but instantiated in Tokelau by his stone in Fakaofo, controlled the weather and the bounty of all natural things, especially the myriad fish of the sea, reef and lagoon, and was annually celebrated in Fakaofo with prayer and offerings. Lister, during his ten-day stay at Fakaofo in 1889, recorded the following report on this annual ritual gathering.

A yearly feast was held in honour of Tui Tokelau, and the people of Nukunonu and Atafu came over with offerings of mats and pearl-shells-the mats hung to the masts of the ships as they approached, to display them. When they landed the mats were wrapped round the stone, to remain until they rotted away, and the pearl-shells were placed along the eaves of the house sacred to the god, close at hand. (1892: 50, my emphasis)

Tui Tokelau's blessings were also regularly acknowledged by symbolically returning to the god what he had provided. From Lister, again, the following note: "If a good haul of fish was taken, part of it would be offered before the stone [of Tui Tokelau] by the king [aliki], and afterwards it was distributed" (1892: 50, my emphasis). Other accounts indicate that all the atolls reciprocated the blessings of Tui Tokelau in this way, that is, the "gift" of the god was symbolically "returned" or acknowledged, and this "gift" was then distributed. ${ }^{14}$

One other feature of Fakaofo's conquest and overlordship is, I think, crucial to an understanding of Lister's "offerings of mats". In the past, not only were kie pandanus treasures produced by Nukunonu women taken to Fakaofo, Nukunonu women were also taken as wives of Fakaofo men. That appropriation is the right word for this "wife-taking" is underscored by its denial of Tokelau customary uxorilocality: a matter invariably noted. Nukunonu women were taken to live and bear their children in Fakaofo. ${ }^{15}$ The 
two appropriations may be linked: both are tied up with reproduction. The women bore children that were "of Fakaofo", alienated from their mothers" käiga and their mothers' brothers. Men's malo conceal and contain male virility, and fine mats, as conjugal sleeping mats, give blessings of fertility. Both retain these associations at Nukunonu weddings, and in the past they were likewise associated with Tui Tokelau. The fine mats that enveloped the stone pillar of Tui Tokelau and the malo that secured them certainly hid, surely contained, and possibly constrained the vital powers of the god. ${ }^{16}$ In "taking" both women and their mats, Fakaofo was actually and symbolically appropriating the reproductive powers associated with Nukunonu.

\section{REFLECTIONS OF THE PAST IN THE PRESENT}

\section{Tokelau Treasures in Tokelau Today}

Today in Tokelau certain kinds of fish called $i k a h \bar{a}$ 'sacred fish'-billfish, turtles (classified as fish) and, most especially, skipjack — must be distributed in village inati. These are exactly the fish reported to be "sacred to Tui Tokelau" and were offered and afterwards distributed in the past. Likewise, any exceptionally good haul of fish today should be distributed, and will be if fishermen are lotonuku 'devoted to village'. Clearly, what was offered to the god and thereafter distributed links the inati distribution system of today to ancient ritual offerings. The fish "sacred to Tui Tokelau" (now simply sacred fish) and abundant fish catches offered to the god and then distributed in the god's name came to be taken to the village and distributed under the aegis of its elders. ${ }^{17}$ The male elders, collectively, have replaced the aliki of the past - they assure the welfare of all. There is a further reflection of that past in the special portion that is set aside for the pastor/priest, whose presence in the village is as the privileged intermediary to the Christian God, now the source of all blessings.

Tokelau treasures are no longer either offered to Tui Tokelau or appropriated by Fakaofo. But Nukunonu's kie pandanus, Atafu's kanava timber and Fakaofo's fresh water continue to be inalienable emblems of the separate places. Nukunonu's kie pandanus is obviously a female valued resource. Women propagate, tend and harvest the plants, process the leaves and plait the fine fibres. In recent years, most Tokelau women plait mats only rarely, but Nukunonu women continue to assemble regularly to plait fine mats and ceremonial men's malo from their kie pandanus (Fig. 14). Kanava timber is a male valued resource from which men laboriously craft canoes (Fig. 15-16). Yet, whereas men are no longer building canoes in Nukunonu and Fakaofo, preferring to import aluminium runabouts, Atafu men are still building new canoes and refurbishing old ones, though they import runabouts too. Thus, the emblematic resources of Atafu and Nukunonu and their associated treasures with their gender attributions are nicely paired. In fact they view 
their relationship in much these terms: Nukunonu gave Atafu's founding father his wife, and so their relationship is one of mother's brother and sister's son.

But what about Fakaofo? It still has its inalienable fresh water and the well in the centre of the village. What does Fakaofo do with its emblematic fresh water? As the other atolls do, it produces something from it, but in a rather less direct way, by digging huge pits down to the freshwater lens and planting swamp taro (pulaka) in them..$^{18}$

The treasured things that are produced from the emblematic resources are not föki tauanoa 'given away indiscriminately'. Rather, they should be given purposefully, in recognition of relationships and attendant obligations. When all Tokelau gathers for pan-Tokelau occasions or to collectively host important guests, Atafu "gifts" tuluma 'cylindrical fishing containers' or model canoes carved from kanava, Nukunonu "gifts" mats incorporating kie pandanus and

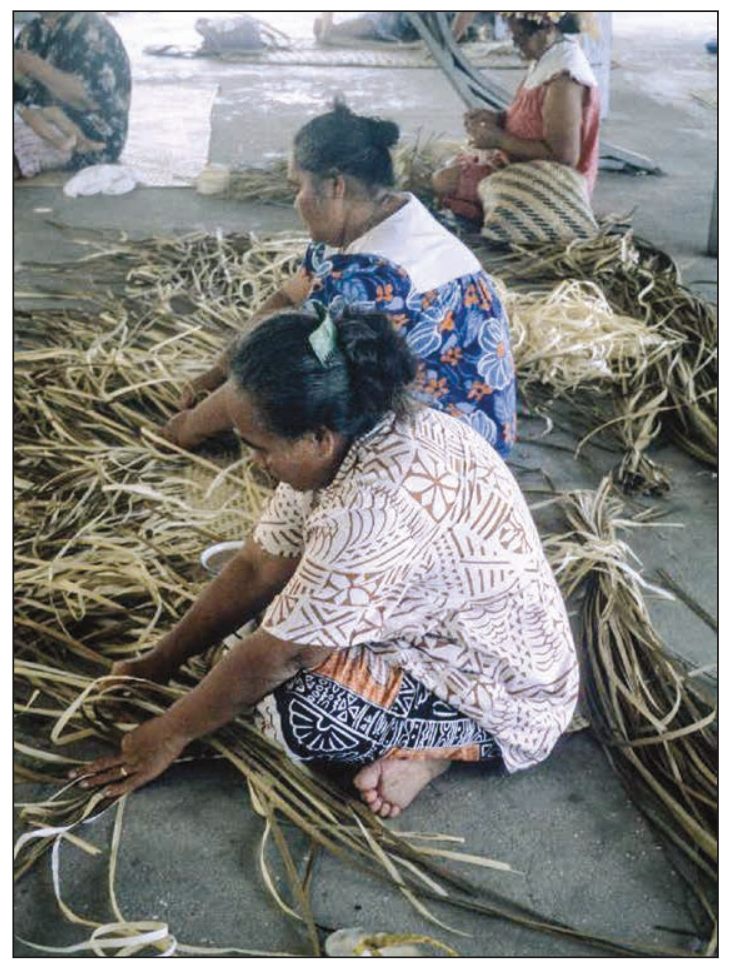

Figure 14. Nukunonu women gather for mat plaiting. Author's photo, 1997. 


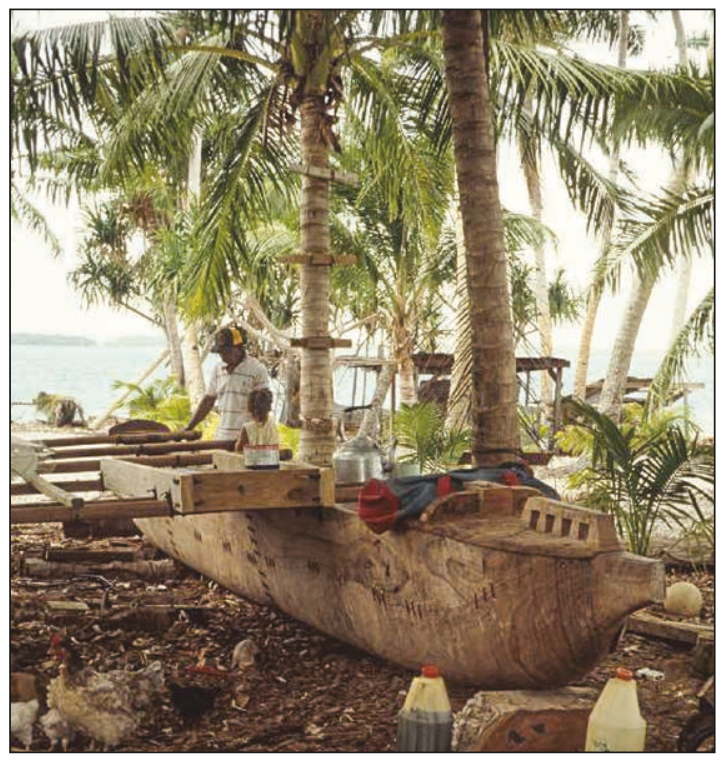

Figure 15. New outrigger canoe being crafted in Atafu. Author's photo, 1991.

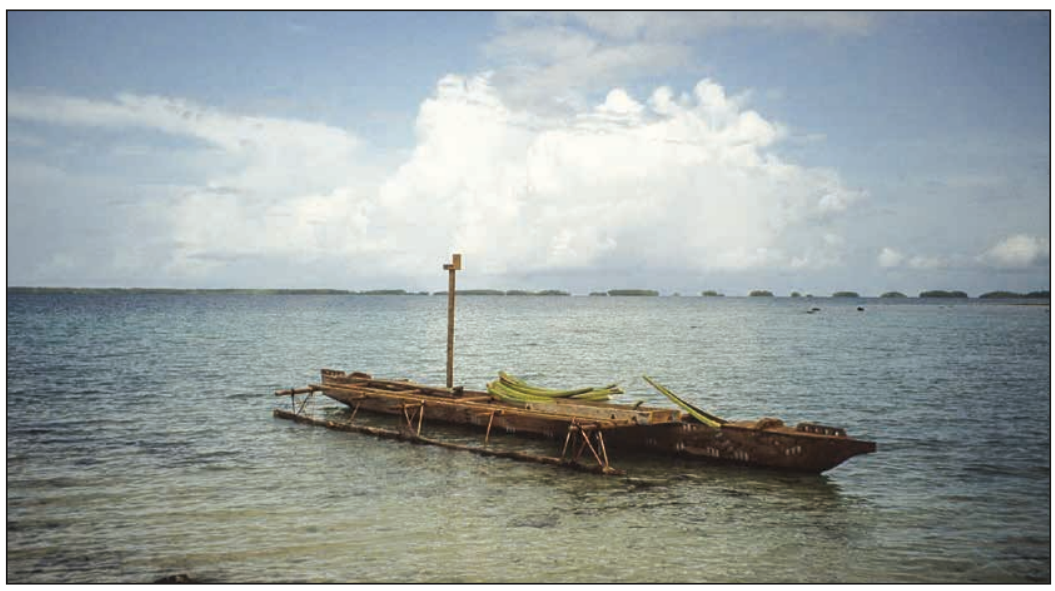

Figure 16. New vaka at anchor. The platform on the stern outrigger booms is for an outboard motor and the raised platform for a lamp to attract flying fish at night. Author's photo, 1991. 
Fakaofo provides delicacies made from swamp taro. Apart from presentations at pan-Tokelau events, the inter-atoll transfers of emblematic resources and treasured objects take place between kin. ${ }^{19}$ A Fakaofo or Nukunonu man with käiga connections in Atafu might seek, and probably receive, kanava timber for a canoe from kin there. Fakaofo or Atafu women with kāiga links in Nukunonu may request and receive a reel of processed kie pandanus from kinswomen there. Fakaofo people give their kin elsewhere parcels of grated and baked swamp taro. This kind of gifting restates (or recreates) the bonds between kin and between the atolls by the transfer of things which are emblems of each and treasured by all.

Pearl-shell, whether as pendants or lures, never figures in this kind of emblematic "gifting". In certain respects tifa/kahoa/p $\bar{a}$ are different from the emblematic things. They are more enduring and cherished treasures. ${ }^{20}$ Take as an instance the death of a notable person: his or her body may be placed in a section of a canoe and covered with a mat (in Nukunonu a fine mat), and a $p \bar{a} /$ kahoa may be placed upon the body. But, before burial, the pearl-shell object is removed, while the canoe section and mat are buried. Today, only at marriage do tifa/kahoa/pa and the kie pandanus appear as counterparts with complementary symbolic qualities, and with certain visual similarities - they both glisten with the luminosity of "an opening gardenia... freshly cut heart of palm... the clouds reflecting the dawning sun", as Tokelau poets have sung. ${ }^{21}$

The symbolic qualities of kie pandanus garments and mats have already been considered above, but what about the pearl-shells that hung around the eaves of "the house of Tui Tokelau"? As distinct from the treasures derived from land-based resources secured in the separate atolls, pearl-shells are found, fortuitously but rarely, in the lagoons. (More often today they are sought and acquired overseas.) They can appropriately be compared to the whale teeth of Fiji in these respects (see Sahlins 1983). However, unlike whale teeth, as $p \bar{a}$ they are used as "means of production", if you will. As kahoa and as they adorned the god-house they are "display items". Once a $p \bar{a}$ is fashioned from a tifa it has a dual nature - a bound $p \bar{a}$ to be used and an unbound kahoa to be displayed - and is always to be treasured.

Recall that the first tifa came from the sky - the abode of both the Sun and Tui Tokelau. This initial "gift" made it possible for men to cast for skipjack, and catches of skipjack were in the past offered before the stone of Tui Tokelau. Was it the blessing of abundance that was being acknowledged, or the "gift" of the tifa? What about the tifa that adorned the god-house in Fakaofo? Were they offerings in recognition of the initial "gift"? Or was their display intended to attract the attention of Tui Tokelau? Or perhaps both? Further, there are the connections between tifa and women. Both of them were taken to or taken by Fakaofo in the past, and they are likened to one another. Recall the exclamations of the old women referring to the nubile 
fafine fou adorned with a kahoa as she stands in the path: "a pearl-shell! ... a new pearl-shell!" This equation of tifa and new woman has puzzled me. I think it less puzzling if the beauty and value of the new woman is being compared to the beauty and value of the tifa, both essential to continuing prosperity. The $p \bar{a}$ that excites skipjack symbolises abundance, a "gift" of Tui Tokelau; the nubile woman adorned with a kahoa - to which she is compared - is the source of human fecundity, again a "gift" of Tui Tokelau.

A Tokelau text (referring to Fakaofo long ago) ${ }^{22}$ explains that when a woman bore her first child she remained cosseted for 40 days. Thereafter, she was dressed, adorned and oiled, and danced before seated onlookers at the malae of Tui Tokelau. By her performance, was she acknowledging Tui Tokelau's "gift"-her child? The "new pearl-shell" had fulfilled the promise that her marriage had anticipated. Women, like pearl-shells, are unique treasures and, like pearl-shells, were once taken to Fakaofo.

\section{Tokelau Treasures in New Zealand}

Today over 7,000 Tokelau people reside in New Zealand. Here the treasures of Tokelau figure too. In the Greater Wellington area, where the largest number of Tokelau people live, those from the separate atolls cluster in specific places and spaces. In the eastern region of the Hutt Valley where many Nukunonu people reside, they congregate at their Hall in Naenae. In Porirua, Pāhina Church Hall is the gathering place for Fakaofo people, and the Atafu community has built their own Matauala Hall on a hilltop. These are not exclusive places; rites of passage and Tokelau celebrations of one sort or another bring Tokelau people together at one venue or another, as do long-running projects of various kinds. Yet, the identity treasures of the atolls still prevail: Nukunonu women gather in their Hutt Valley Hall every Wednesday at 10:30 a.m. to plait mats from pandanus sent by women in the atoll, and a group of weavers made a video both instructive and celebratory; at Matauala Hall, Atafu elders built a Tokelau outrigger canoe and wrote a book detailing Atafu fishing practices (Elders from Atafu Atoll 2012, Mafutaga a Toeaina o Atafu i Matauala Porirua 2008). Again, we see that Fakaofo's identifying treasure is not portable. However, their church hall Pāhina ( $p \bar{a}$ 'skipjack lure', hina 'white') does perhaps reference the house of Tui Tokelau with pearl-shells hanging from its eaves. But then tifa/pä/kahoa were and are pan-Tokelau treasures. In recent years, so-called kahoa have increasingly become neck adornments of Tokelau girls and young women. Usually they are fashioned from the thin marginal sections of tifa-one enterprising Fakaofo man even fashions them for sale. They have become icons of Tokelau ancestry. Yet, the words of the text of that Tokelau elder, composed at least a half-century ago- - "It is unseemly in these days the way 
kahoa are so often displayed"- - have been echoed in a different context today: "These pearl-shell ornaments are not really kahoa." This is because of the ways they are acquired and given, but more to the point, because they were never laboriously fashioned and properly bound $p \bar{a}$ that excited skipjack.

$$
* * *
$$

Tokelau treasures appear never to have been transacted. In the past they were stolen by spirits and "gifted/appropriated" in the name of Tui Tokelau; in the present they are transferred, primarily as expressions of alofa 'devotion/ compassion' and manuia. The most "singular" treasure is pearl-shell, cherished and admired, fashioned into lures to excite skipjack and then transferred among Tokelau men through women. They are never exchanged for something else, or indeed given in expectation of a return. How they are transferred indeed makes either impossible - the "Tale of the Pearl-Shell" warns of the consequences of doing otherwise.

In New Zealand, the treasures of Tokelau have taken on new meanings: they have become icons of identity as "of Nukunonu", "of Atafu", "of Fakaofo" within the community, while pearl-shell neck adornments identify the wearers as "of Tokelau" within New Zealand. Cultural treasures indeed have a history-in new contexts they take on new meanings while retaining echoes of their meanings in the past.

\section{ACKNOWLEDGEMENTS}

This essay has a long history-I fear too long for me to recall all my debts. Its beginning was a working paper at the ASAO conference in 1996, and later that year it was revised for an Anthropology Department Seminar at the University of Auckland. I worked on it again for a workshop in Marseille in 2001 and immediately thereafter. Subsequently I tinkered with it from time to time, before revising it yet again as the Nayacakalou Lecture. I gratefully acknowledge the late Antony Hooper for his cogent corrections and, more particularly, for his complementary and collegial contributions to the narrative of Tokelau.

\section{NOTES}

1. My usage of "singular" here and by contrast "common" follows Kopytoff 1986. I thus avoid the term "commodity" that seems so out of keeping in the Tokelau context, except for imported store-bought items (see following note).

2. One might say that Tokelau formal structures of exchange in the broad sense, i.e., the transfer of things by people, eschew any kind of exchange in the narrow sense, i.e., dyadic, commodity transactions between individuals or groups. Things produced by fishing, harvesting or processing are regularly, even daily, brought together and apportioned throughout the village or among some recognised group 
within it. These transfers are a classic exemplification of Sahlins' "pooling" and "redistribution" (1965: 141-43), except there are no chiefs involved. Rather they occur either under the aegis of the collective toeaina 'elders' in village pooling, or under the aegis of tuafafine 'sisters' in käiga pooling. Informal exchange in the broad sense again is decidedly not conducted as exchange in a narrow sense. People regularly request and receive things from their kin and neighbours (it is often difficult to tell which is which in a Tokelau village), and foodstuffs are continually being transferred to neighbours or to kin. To immediately give something in return would be decidedly crass. Properly, things are given out of alofa, not in expectation of return. The Tokelau lexicon reflects this emphasis on pooling and aversion to dyadic transactions. There are numerous lexemes, in both nominal and verbal forms, for distributing, allocating, dividing and apportioning, and none for reciprocal exchange, excepting the compound fefakatauaki composed of fe...aki 'mutual, reciprocal' and fakatau 'shopping, trade' (or perhaps fakafetōlaki which may simply be glossed as 'swap', that is to exchange like for like, as when today's young people swap T-shirts). Tokelau people do speak about reciprocal exchange in the foreign context of shopkeepers and traders, though it is rather cumbersome to do so, and certainly not in keeping with how things should be done among themselves.

3. Tokelau inati is obviously cognate with, for example, Tongan inasi. The widespread form is among the reconstructed Proto-Polynesian lexemes, glossed as 'share, portion' (Biggs and Clark 2010). In Tokelau today, every person in a village is assigned to one and only one inati, and these 'share units' are weighted according to how many persons are assigned to them. The outcome of any inati distribution is that each person in the village, irrespective of age, gender or status, receives, in principle, an equal portion (see Huntsman and Hooper 1996: 76-83).

4. Village endogamy is pragmatic, not prescriptive. Natal villages are usually where people's resources and support are strongest, and where their loyalties and obligations lie. There is an obvious conundrum here, given the Tokelau concepts of marriage proprieties - one should not marry kin - which I am not going to examine here, but see Huntsman and Hooper 1976. Yet, while villagers may be categorised as "mothers", "fathers", "sons" and "daughters", they are only referred to collectively as brothers or sisters in single-sex contexts, that is, as taina or uho 'same-sex siblings'. Complementary brothers (tuagane) and sisters (tuafafine) are the focus (or structural pivot) of käiga, discriminating between its members as tamatāne 'issue of brothers' and tamafafine 'issue of sisters', each with specific rights and obligations (for more, see Huntsman 1971, 1981, Huntsman and Hooper 1996: Ch. 3).

5. Kanava (Cordia subcordata) is a slow-growing hardwood and the only timber locally available for fashioning long-lasting canoe hulls. The trees themselves are treasures, part of the endowment of a käiga. Käiga canoes were essential to provisioning the kin group - large ones commodious enough to transfer coconut provisions from käiga lands and smaller ones for ocean fishing. In the 1970s they began to be replaced by aluminium runabouts equipped with outboard motors, and by the 1990s they had virtually been replaced, except in Atafu Atoll (see text below). 
6. Käiga landholdings consist of more or less extensive stands of coconut palms and other vegetation located on different islets of the atoll. These may be allocated or divided. Canoes are likely to be unlashed and the hull sections allocated. Canoe hull sections may be used as coffins (vaka referents are both 'canoe' and 'coffin'). They may be sections just lying around or set aside for the purpose. However, in cases of significant senior members of a käiga, a canoe may be dismantled for the purpose. It is said that this was a test of the integrity of that käiga-in the absence of the elder could the kaiga work together to restore the canoe, or would the kaiiga too be malepe 'broken up'?

7. Nukunonu rites of passage (celebrations of marriage, first birth and death) are self-consciously traditional. This traditionalism may be attributed to Catholic tolerance of local practices in the 19th century (versus Protestant repression), which Nukunonu Catholics celebrate and Protestants elsewhere acknowledge. I draw this account from three celebrations in 1967-68.

8. The new couple is only potentially a new family and only actually becomes one when a child is born of the union, ensuring the generational continuity that is the essence of kaiga. The fine kiekie mat gifted by the man's father's sister most clearly expresses this manuia, for the father's sister is attributed with powers to bless or curse the offspring of her brother (as in Tonga and Sāmoa). The kahoa is more opaque in this regard. Its centrality as a lure shank for a $p \bar{a}$ in the most elaborated Tokelau fishing practice links it more to provision/production than reproduction (but see text below).

9. The late Peato Tutu Perez composed the text (in Tokelauan) from which this passage is excerpted and translated by the author. He authenticated his text by attributing his knowledge to his grandfather, and saw this text and others as legacies concerning the Tokelau past for future Tokelauans. The practices described are generally placed in the past and in Fakaofo, and no mention is made of Christian marriage vows, though Peato was a Catholic catechist. Nonetheless what he described is clearly reflected in more recent practice. Another of Peato's texts, Kuри о te moana 'words of the sea', includes a finely detailed description of the Tokelau method and etiquette of casting for skipjack (Hooper and Huntsman 1991) and in 1960 he composed a Tokelau text on Tokelau treasures for a school reader (reprinted in English as Perez 1992).

10. There are exceptions to this statement. When men are inducted as tautai 'master fishermen' after they have proven their skills as fishermen, established tautai "gift" fishing tackle of various sorts, including lures for skipjack casting, to these new tautai. This gifting is within a communal context-the new tautai are being recognised as accomplished providers mo te manuia o te nuku katoa 'for the welfare of all'. Likewise, the etiquette of communal skipjack casting calls for tautai to provide $p \bar{a}$ to those of their compatriots who for one reason or another have none. Again, this is "for the welfare of all".

11. In the Tokelau gendering of their world, fish are gender-feminine and the birds that prey upon them are gender-masculine. This I assert on the basis of analogies in other kakai, though no Tokelau person has ever directly said so. For further discussion of gendering in Tokelau, see Huntsman and Hooper 1975. 
12. Tui Tokelau features in Tokelau traditions only after Fakaofo establishes preeminence and, Tokelau sages assert, never had human form. The name does not appear in Tokelau founding genealogies.

13. Aliki figured in the religious and political life of Tokelau until the mid-19th century, as the leo 'voice' of the collectivity to the gods and of decisions reached by the elders to the polity. In recent times the oldest man in a village voices important decisions of the elders (see Hooper 1994 and Huntsman 1994).

14. This resonates with Mauss's concept of the hau of The Gift (1954) as this concept has been revisited and revised by other scholars (see especially Godelier 1999).

15. Nukunonu local histories and genealogies attest to this transfer. However, the Nukunonu interpretation tends to view it as "wife-giving" by means of which significant kinship links were established with (and in) Fakaofo (Huntsman and Hooper 1985). The impressionistic but consistent demographic observations that Nukunonu had a far smaller population than Fakaofo again support the assertion that Nukunonu's women were given or appropriated.

16. I assert this based on Polynesian analogies elsewhere; Tokelauans have not said so.

17. Casting for skipjack is properly done communally, with all able men going to the fishing grounds together in a fleet of canoes (refer to Figs 6 and 7). Sometimes one or more skipjack are hooked in the course of regular fishing, in which case they are sensibly not shared in inati, though the fishermen (or the 'sister' who allocates the catch) may pointedly send them to particular people, such as an elder, a pregnant woman or someone who is ill. Billfish and turtles - as well as any communal catches - are always distributed through inati. More generally, the idea of treating any fish as a saleable commodity is shunned. In recent years individual entrepreneurial fishing ventures have been thwarted, indeed sabotaged. Even what seemed rational communal enterprises - supported by external aidhave been thoroughly compromised. Fish, simply, must not be sold to enrich a few, but shared for the benefit of all — that is Tokelau aganuku 'hallowed custom'.

18. Pulaka production was introduced and promoted by Cook Island and Tuvalu pastors in the late 1800 s and greatly increased in the 1930 s by vastly expanding the area of the excavated pits.

19. In this way, non-resident käiga members, who cannot receive their rightful shares in regular käiga distributions of produce, are recognised with special gifts.

20. Pearl-shells are now very rarely found in Tokelau lagoons (though this may not have been the case in the distant past), but are sought afar from, for example, the northern Cook Islands, Tahiti and Papua New Guinea.

21. See "The Tale of Alo" in Matagi Tokelau (1991: 210) or Songs and Stories of Tokelau (Thomas et al. 1990: 78). Godelier (1999: 166) equates the association of gold and the Sun in ancient Egypt with the association of mother-of-pearl with gods elsewhere, commenting: "it was the mother-of-pearl... that captured the imagination of societies which saw in the iridescent whiteness the presence of life, the trace of the sperm of the gods and that of men". The latter association does not seem widely generalisable to me, but the "iridescent whiteness" might translate into Tokelauan as gigila 'glitter, sparkle, glisten', something that dazzles the eyes.

22. Again the text was composed by Peato Tutu Perez (see note 9 above). 


\section{REFERENCES}

Best, Simon, 1988. Tokelau archaeology: A preliminary report of an initial excavation. Indo-Pacific Prehistory Association Bulletin 8: 104-18.

Biggs, Bruce and Ross Clark (compilers and eds), 2010. POLLEX, Proto Polynesian Lexicon. POLLEX-Online at: https://researchspace.auckland.ac.nz/docs/uoadocs/rights.htm

Burrows, W., 1923. Some notes and legends of a South Sea island. Journal of the Polynesian Society 32: 143-73.

Elders from Atafu Atoll, 2012. Echoes at Fishermen's Rock: Traditional Tokelau Fishing. Translated and edited by A. Hooper and I. Tinielu. Knowledges of Nature 4. Paris: UNESCO.

Ella, S. MS. Letter dated Fasitootai 27 November 1861. London Missionary Society, South Sea Letters. Microfilm, Alexander Turnbull Library, Wellington.

Godelier, Maurice, 1999. The Enigma of the Gift. Chicago: University of Chicago Press. Hale, Horatio, 1846. United States Exploring Expedition. During the Years 1838, 1839, 1840, 1841, 1842. Under the Command of Charles Wilkes, U.S.N.: Ethnography and Philology. Philadelphia: Lea and Blanchard.

Hooper, Antony, 1985. Tokelau fishing in traditional and modern contexts. In K. Ruddle and R.E. Johannes (eds), Traditional Knowledge and Management of Coastal Systems in Asia and the Pacific. Jakarta: UNESCO, pp. 7-38.

1994. Ghosts of hierarchy I: The transformation of chiefly authority on Fakaofo, Tokelau. In M. Jolly and M. Mosko (eds), Transformations of Hierarchy. Vol. 7 of History and Anthropology. Cambridge: Harwood Academic, pp. 307-20.

2010. Two Tokelau fishing texts. Journal of the Polynesian Society 119 (3): 227-268.

Hooper, Antony and Judith Huntsman, 1991. Aspects of skipjack fishing: Some Tokelau 'words of the sea'. In A. Pawley (ed.), Man and a Half: Essays in Pacific Anthropology and Ethnobiology in Honour of Ralph Bulmer. Auckland: The Polynesian Society, pp. 249-56.

Hudson, C.W.L., MS. Journal of U.S. Exploring Expedition, 11 August 1840 to 19 February 1842. Canberra: Pacific Manuscripts Bureau, Microfilm 416.

Huntsman, Judith, 1971. Concepts of kinship and categories of kinsmen in the Tokelau Islands. Journal of the Polynesian Society, 80: 317-54.

1981. Complementary and similar kinsmen in Tokelau. In M. Marshall (ed.), Siblingship in Oceania. ASAO Monograph No. 8. Ann Arbor, Michigan: UMI Monographs, pp. 79-103.

1994. Ghosts of hierarchy II: Transformations of the wider Tokelau polity. In M. Jolly and M. Mosko (eds), Transformations of Hierarchy. Vol. 7 of History and Anthropology. Cambridge: Harwood Academic, pp. 321-38.

Huntsman, Judith and Antony Hooper, 1975. Male and female in Tokelau culture. Journal of the Polynesian Society 84 (1): 415-30.

1976. The 'desecration' of Tokelau kinship. Journal of the Polynesian Society 85: 257-93.

1985. Structures of Tokelau history. In A. Hooper and J. Huntsman (eds), Transformations of Polynesian Culture. Auckland: Polynesian Society Memoir 45, pp. 133-49. 
1996. Tokelau: A Historical Ethnography. Auckland: Auckland University Press. Kopytoff, Igor, 1986. The cultural biography of things: Commoditization as process. In A. Appadurai (ed.), The Social Life of Things. New York: Cambridge University Press, pp. 64-91.

Lister, J.J., 1892. Notes on the natives of Fakaofu [sic] (Bowditch Island), Union group. Journal of the Anthropological Institute 21: 43-63.

Mafutaga a Toeaina o Atafu i Matauala Porirua, 2008. Hikuleo i te Papa o Tautai. Wellington (NZ): Steele Roberts.

Matagi Tokelau, 1991. Matagi Tokelau: History and Traditions of Tokelau. English edition, Translated from Tokelau and edited by J. Huntsman and A. Hooper. Apia: Office of Tokelau Affairs, and Suva: Institute of Pacific Affairs, University of the South Pacific.

Mauss, Marcel, 1954 [1925]. The Gift: Forms and Functions of Exchange in Archaic Societies. [English translation]. London: Routledge \& Kegan Paul.

Perez, Peato Tutu, 1992. Ko te Koloa a Tokelau. Wellington: Learning Media, Ministry of Education. [English version of 1960 text in Tokelauan from series Tuhi Tala mo Tamaiti Tokelau.]

Sahlins, Marshall, 1965. On the sociology of primitive exchange. In M. Banton (ed.), The Relevance of Models for Social Anthropology. ASA. Monograph 1. New York and Washington: Praeger, pp. 139-236.

-1983. Raw women, cooked men, and other "great things" of the Fiji Islands. In P. Brown and D. Tuzin (eds), The Ethnography of Cannibalism. Special Publication, Society for Psychological Anthropology, pp.72-93.

Thomas, Allan, Ineleo Tuia and Judith Huntsman (eds), 1990. Songs and Stories of Tokelau: An Introduction to the Cultural Heritage. Wellington: Victoria University Press.

\section{ABSTRACT}

Drawing upon multiple lines of research in and about Tokelau - ethnography as participant-observation and conversation/discussion, documentary research in all available published sources (few) and unpublished materials in offices and archives, Tokelau narratives and texts, conversations with other scholars of Tokelau, and relevant anthropological literature - the late Antony Hooper and I have aimed to create a narrative of Tokelau over time and in places that speaks to both differences and continuities in Tokelau lifeways - their activities and beliefs, ideas and relationships. This essay is a contribution to and illustration of our endeavours, focusing on those particular things that Tokelau people treasure: their emblematic resources and the valued things they make from them, and their supreme valued treasures - pearl-shells (tifa), and the lures ( $p \bar{a})$ and pendants (kahoa) fashioned from them.

Keywords: pearl-shells, skipjack casting, Tui Tokelau, emblematic resources, cultural histories of things, Tokelau

\section{CITATION AND AUTHOR CONTACT DETAILS}

Huntsman, ${ }^{1}$ Judith. 2017. The treasured things of Tokelau. Journal of the Polynesian Society 126 (3): 253-282. DOI: http://dx.doi.org/10.15286/jps.126.3.253-282

${ }^{1}$ Correspondence: Anthropology, School of Social Science, University of Auckland, Private Bag 92019, Auckland 1142, New Zealand. Email: j.huntsman@auckland. ac.nz 